\title{
Trade-offs in seedling survival, growth, and physiology among hardwood species of contrasting successional status along a light- availability gradient
}

\author{
Christopher M. Kaelke, Eric L. Kruger, and Peter B. Reich
}

\begin{abstract}
To better understand the regeneration ecology of northern red oak (Quercus rubra L.) in mesic forests, we compared its seedling growth and physiology with those of two other hardwoods, differing in successional status, along a gradient in light availability ranging from forest understories (2.6\% of full light) to small clearings (69\% of full light). Oak's relative growth rate (RGR) closely resembled that of shade-tolerant sugar maple (Acer saccharum Marsh.), and the positive response of both to increasing light was modest, especially beyond a relative light availability of $15 \%$. Intolerant trembling aspen (Populus tremuloides Michx.) outgrew the others when relative light availability exceeded $5 \%$, and its RGR increased more or less linearly with increasing light. However, there was a rank reversal of RGR in deep shade, where maple and oak had a higher RGR than aspen. This reversal was mirrored by seedling demography, as aspen survival was comparatively high in small clearings but negligible in deep shade. Aspen's low RGR and poor survival in low light were associated with a high rate of shoot dark respiration and minimal allocation to starch reserves. Aspen's high RGR in openings was attributed primarily to a high photosynthetic capacity per unit leaf mass. Thus, differential growth and survival among species could be explained in part by trade-offs in attributes that promoted rapid growth in high light at the expense of a favorable carbon balance in low light, or vice versa. Oak's suite of traits facilitated a positive carbon balance in perhaps all but the darkest understories. We suggest that the lack of persistence of oak seedlings in many understory environments may center around factors (e.g., vulnerability to biotic stresses) not directly related to carbon gain.
\end{abstract}

Résumé : De façon à mieux comprendre l'écologie de la régénération du chêne rouge (Quercus rubra L.) dans les forêts mésiques, nous avons comparé la croissance et la physiologie de ses semis avec celles de deux autres feuillus de statut sérial différent, le long d'un gradient de disponibilité en lumière variant du sous-étage forestier $(2,6 \%$ de la pleine lumière) à de petites clairières (69\% de la pleine lumière). Le taux de croissance relatif (RGR) du chêne ressemblait fortement à celui de l'érable à sucre (Acer saccharum Marsh.), qui est tolérant à l'ombre, et la réponse positive des deux essences à l'augmentation de la lumière était modeste, particulièrement sous une disponibilité relative en lumière supérieure à $15 \%$. Le peuplier faux-tremble (Populus tremuloides Michx.), qui est intolérant, dominait les autres essences dès que la disponibilité relative en lumière dépassait 5\% et son RGR augmentait de façon plus ou moins linéaire avec l'augmentation de la disponibilité en lumière. Il y avait toutefois une inversion de rang du RGR dans des conditions de très faible intensité lumineuse, où l'érable et le chêne avaient un RGR plus élevé que celui du peuplier. Cette inversion était reflétée par la démographie des semis, puisque le taux de survie du peuplier était comparativement plus élevé dans les petites clairières mais négligeable dans des conditions de très faible intensité lumineuse. Le faible RGR du peuplier et le faible taux de survie dans des conditions de faible intensité lumineuse étaient associés à un taux élevé de la respiration à la noirceur et à une allocation minimale aux réserves en amidon. Le RGR élevé du peuplier dans les clairières était attribué principalement à une capacité photosynthétique par unité de masse foliaire élevée. Par conséquent, les différences dans la croissance et le taux de survie entre les espèces pourraient s'expliquer en partie par des compromis dans les attributs qui favorisent une croissance rapide sous de fortes disponibilités en lumière au prix d'un bilan favorable en carbone dans des conditions de très faible intensité lumineuse et vice versa. Les différentes caractéristiques du chêne favorisent un bilan du carbone positif sous tous les couverts, à l'exception des plus sombres. Nous croyons que le manque de persistance des semis de chêne dans de nombreux environnements sous couvert pourrait s'expliquer par des facteurs (e.g., vulnérabilité aux stress biotiques) non directement reliés aux gains en carbone.

[Traduit par la Rédaction]

Received August 29, 2000. Accepted May 1, 2001. Published on the NRC Research Press Web site at http://cjfr.nrc.ca on September 6, 2001.

C.M. Kaelke. Department of Natural Resources and Environmental Sciences, University of Illinois at Urbana-Champaign, Urbana, IL 61801, U.S.A.

E.L. Kruger. ${ }^{1}$ Department of Forest Ecology and Management, University of Wisconsin-Madison, Madison, WI 53706, U.S.A.

P.B. Reich. College of Forest Resources, University of Minnesota, St. Paul, MN 55108, U.S.A.

${ }^{1}$ Corresponding author (e-mail: elkruger@facstaff.wisc.edu). 


\section{Introduction}

Much has been learned about ecophysiological differences among tree species varying in successional status and shade or understory tolerance (Bazzaz and Wayne 1994; Messier et al. 1999; Walters and Reich 1999). Nevertheless, it is not yet possible to fully explain the demography of tree regeneration along gradients in light availability. Further progress on this front would benefit efforts addressing difficult regeneration challenges, such as that concerning northern red oak (Quercus rubra L). The prevalence of this species and several of its congeners is declining in eastern deciduous forests of North America, especially on productive sites (Pallardy et al. 1988; Spencer and Kingsley 1991; Stephens and Ward 1992). The root of this trend is a widespread but incompletely understood failure of oak regeneration to recruit into existing or developing canopies in mesic forests (Crow 1988; Lorimer 1989; Abrams 1992; Johnson 1993).

Since the general recognition of this problem several decades ago, silviculturists have been searching for stand manipulations that facilitate oak re-establishment. The primary intent of current prescriptions, such as the shelterwood system, is to create a favorable light environment (Johnson 1993; Lorimer 1993; Gordon et al. 1995). To date, however, none of these strategies have met with consistent success (Johnson 1993), and the existence of a light environment in which northern red oak can effectively compete with mesic forest vegetation has yet to be clearly demonstrated. Although northern red oak is often classified as mid-tolerant (Burns and Honkala 1990), its ecology has proven enigmatic and may not fit squarely within any discrete portion of a light-availability gradient. Slow juvenile growth places it at a competitive disadvantage in mesic forest openings (Kruger and Reich 1997a, 1997c), while at the same time, it rarely persists beyond the seedling stage in mesic understories (Crow 1988; Johnson 1993; Lorimer et al. 1994).

Considerable insight has been generated regarding the nature of northern red oak's comparatively low growth potential in high-resource environments (Farmer 1980; Walters et al. 1993b; Kruger and Reich 1997c) as well as its response to light availability (e.g., Loach 1967, 1970; Geis et al. 1971; Musselman and Gatherum 1969; Phares 1971; Farmer 1975; Ashby 1976; Hanson et al. 1987; Gottschalk 1987; Walters and Reich 1996). However, the vast majority of this work was conducted using potted seedlings in artificial environments, wherein it was difficult to adequately simulate the temporal and spatial dynamics in light (Canham et al. 1990), let alone the myriad of biotic and abiotic factors that may (or may not) covary with light, in a forest (Toumey and Kienholz 1931; Shirley 1943; Pearcy 1987; Wayne and Bazzaz 1993; Bazzaz and Wayne 1994; Coomes and Grubb 2000). It is increasingly apparent that tree seedling performance under artificial conditions may not always correlate adequately with that in natural habitats (e.g., Kolb and Steiner 1990; Burton and Bazzaz 1995; Dillenburg et al. 1995).

Our principal objective in the present study was to determine, in a mesic forest setting, northern red oak's growth response along a gradient in light availability ranging from understories to large openings and to elucidate the morphological and physiological traits shaping its response. We provided a framework for this assessment by comparing oak's performance with the growth and physiology of two sympatric hardwood species differing widely in successional status and shade tolerance, trembling aspen (Populus tremuloides Michx.) and sugar maple (Acer saccharum Marsh.). Aspen is an early successional, shade-intolerant species that aggressively colonizes larger gaps, whereas maple is a late-successional, shade-tolerant species that often forms dense regeneration layers in mesic forest understories (Curtis 1959).

The general premise underlying our approach is that plant species exhibit relative performance optima (e.g., higher growth rates and percent survival than potential competitors) at different positions along environmental gradients and that these positions define a species' ecology and successional status (Canham and Marks 1985). One can find empirical support for this theory of shifting competitive hierarchies (Keddy 1989) in studies of tree response to light availability (e.g., Latham 1992; Pacala et al. 1994). In the present study, we anticipated that the relative growth rate of putatively mid-tolerant oak would exceed those of aspen and maple at moderate light availabilities (e.g., in small gaps), whereas it would be outpaced by maple in the understory and aspen in larger openings. We also hypothesized that shifts in growth rankings along the light gradient would be accompanied by trade-offs in physiological traits that would promote either rapid growth in high light or persistence in low light but not both.

\section{Materials and methods}

\section{Study sites and experimental approach}

The study was conducted during 1994-1996 in two mesic, mixed hardwood forests in southwestern Wisconsin. One was located near Baraboo, Wis. $\left(43^{\circ} 26^{\prime} \mathrm{N}, 89^{\circ} 50^{\prime} \mathrm{W}\right)$, and the other near Dodgeville, Wis. $\left(42^{\circ} 59^{\prime} \mathrm{N}, 90^{\circ} 07^{\prime} \mathrm{W}\right)$. The two forest overstories were similar in composition and included individuals of the three study species as well as basswood (Tilia americana L.), white ash (Fraxinus americana L.), white oak (Quercus alba L.), bitternut hickory (Carya cordiformis (Wangenh.) K. Koch), and slippery elm (Ulmus rubra Muhl.). Based on data from a weather station near Dodgeville, the 30-year average for annual precipitation in the area is $81 \mathrm{~cm}$, while average monthly temperatures range from $-9^{\circ} \mathrm{C}$ in January to $22^{\circ} \mathrm{C}$ in July (U.S. Department of Commerce 1994). In 1994, rainfall during June through September amounted to $52 \mathrm{~cm}$, which was $35 \%$ greater than the 30-year average for that period (U.S. Department of Commerce 1994). The Baraboo study site was a relatively flat terrace at the base of a north-facing slope, while the Dodgeville site was on a $15 \%$ slope with a northeastern aspect. The soils at both sites were Typic Hapludalfs, consisting of a silt loam cap (15-32 cm in depth) overlying either a thick horizon of clay (at Baraboo) or a matrix of clay and dolomite residuum (at Dodgeville) (USDA 1962, 1980). Both sites were selectively logged 6-10 years prior to the study, creating a wide range of light environments within each.

At each site, six $4 \times 4 \mathrm{~m}$ plots were established in dimly lit understories, beneath partial overstories, in small clearings or along their edges. To minimize heterogeneity in growing conditions within a plot, the shoots of extant woody undergrowth $(<2 \mathrm{~cm}$ diameter at breast height) were manually removed from all plots prior to planting and throughout the remainder of the study. Each plot was fenced with hardware cloth $(0.6 \mathrm{~cm}$ mesh) that was electrified around the top to prevent herbivory by mammals. Despite this protection, one plot at Dodgeville had to be abandoned early in 
the study because of heavy acorn predation by rodents. No mammal damage was observed in the remaining plots.

\section{Plant material and growth conditions}

Seeds of trembling aspen were provided by the University of Minnesota North Central Experiment Station, Grand Rapids, Minn. Acorns of northern red oak were collected near the Baraboo site in the fall of 1993. Owing to an inadequate crop of maple seed in 1993, one-year-old seedlings of sugar maple were obtained at each site, in locations less than $30 \mathrm{~m}$ from the growth plots, at the onset of the study. In late April 1994, aspen seeds were germinated under partial shade on commercial potting medium, and germinants were then transferred to book planters containing the same potting medium in a greenhouse. Oak acorns were germinated on moist paper in mid-May 1994 and remained there until outplanting. Germinants of aspen and oak were transplanted to the study plots during the first week of June 1994. At the same time, 1-year-old maple seedlings were transplanted (with roots in a soil hemisphere of about $5 \mathrm{~cm}$ radius) from areas possessing similar light availabilities to that of the plot in which they were placed. In every plot, 25 individuals each of aspen and maple, along with 20 oak germinants, were randomly assigned to positions in a grid based on a $20 \times$ $25 \mathrm{~cm}$ spacing. The minimum distance between grid perimeter and plot fence was $1 \mathrm{~m}$.

\section{Measures of seedling growth and mass distribution}

Sequential whole-seedling harvests of five individuals per species were conducted on each plot in mid-July and mid-August of 1994. Additional seedlings (two to five per plot) were harvested after leaf abscission in November 1994 and again prior to bud break in April 1996. At the time of transplanting in June 1994, 12 aspen and 18 maple seedlings (randomly selected from all transplants) were harvested to obtain initial dry mass and leaf area. The initial (June) mass of all oak seedlings was taken to be the average dry mass of seven randomly selected acorns (excluding the pericarp). The mean dry mass of aspen, maple, and oak in June was 0.18 , 0.31 , and $1.09 \mathrm{~g}$, respectively.

At all harvests, seedlings were excavated and stored on ice until they were processed. At the June, July, and August harvests in 1994, seedlings were sorted into leaves, stems, and roots, and fresh leaf areas were determined with a LI-COR 3100 leaf area meter (LI-COR Inc., Lincoln, Nebr.). At every harvest, roots were rinsed free of soil, and all plant material was dried to a constant mass in a forced-air oven at $70^{\circ} \mathrm{C}$ and weighed. By the time of the July harvest, oak cotyledon reserves appeared to be exhausted (most cotyledons were withered and dark-colored, and many had detached from the germinant); thus, cotyledons were not included in mass measurements.

Harvest data from July and August 1994 were used to measure relative growth rate (RGR; $\mathrm{mg} \cdot \mathrm{g}^{-1} \cdot \mathrm{day}^{-1}$ ) during that interval, which was calculated for individual seedlings as (ln(August dry mass) - $\ln ($ July dry mass))/time (Evans 1972). At each of those harvests we also measured specific leaf area (SLA; $\mathrm{m}^{2} \cdot \mathrm{kg}^{-1}$ ) and the mass ratio $\left(\mathrm{g} \cdot \mathrm{g}^{-1}\right)$ of leaves (LMR), stems (SMR), and roots (RMR). In addition, we determined patterns of mass allocation during the interval by calculating the percentage of acquired mass that was allocated to a given organ as ( $\Delta$ organ mass/ $\Delta$ seedling mass $) \times 100$. We adopted this approach rather than allometry (i.e., mass of organ $Y=a$ (mass of organ $X)^{b}$; Ledig et al. 1970; McConnaughay and Coleman 1999), because our intent was to compare allocation patterns at the whole-seedling level. Since an allometric coefficient $(b)$ is the ratio of RGRs of two plant components (i.e., $\mathrm{RGR}_{\text {organ }} / \mathrm{RGR}_{\text {plant }}$ ), it does not reflect the proportionality of total mass allocation if organ mass ratios differ initially. Correspondingly, it is not a reasonable basis for comparison of whole-seedling allocation when organ mass ratios vary among spe- cies and (or) environments at the outset, which was the case in our study.

For each individual harvested in August, seedling mass and organ mass ratios in July were estimated using species-level allometric relationships, generated from July harvest data, between total or organ dry mass and either stem height (for aspen) or firstflush leaf mass (for oak and maple). The first leaf flush had expanded fully by early July, and its area was readily determined on seedlings harvested in August. This measure was converted to a July mass estimate based on species $\times$ plot averages for SLA at the July harvest. Regression slopes and intercepts did not vary significantly among sites or plots, and the $r^{2}$ of these relationships ranged from 0.73 to 0.95 ( $48 \leq n \leq 53, P<0.0001)$.

Data from subsequent harvests were used to assess net growth during the 1994 growing season (June through October) and cumulative net growth through the growing seasons of 1994 and 1995, which were relativized $\left(\mathrm{g} \cdot \mathrm{g}^{-1}\right)$ using the equation, $\ln$ (final dry mass) - $\ln$ (initial dry mass). In these calculations, because data on first-flush leaf area were lacking for maple and oak, the initial mass of a given species (including aspen) on every plot was set equal to the average mass of all individuals of that species harvested in June 1994.

\section{Measures of leaf nitrogen and seedling starch concentrations}

Samples of ground foliage from each species and plot, pooled across the July and August harvests in 1994, were analyzed for nitrogen concentration using a micro-Kjeldahl method (Schulte et al. 1987). The amount of leaf and nonleaf (stem + root) dry mass composed of starch, the primary storage carbohydrate in all three species (Dickson 1991), was also determined for every species and plot at the August harvest. Dried leaf and nonleaf (stem + root) tissues were analyzed separately for starch concentration using methods outlined by Lindroth et al. (1993).

\section{Measures of leaf photosynthesis and shoot dark respiration}

In every plot, gas exchange was measured on one leaf from each of three seedlings per species with a portable LCA-2 infrared gas analyzer and a Parkinson broadleaf cuvette (Analytical Development Corporation, Hoddesdon, U.K.), operated as an open system with a column of $\mathrm{Mg}\left(\mathrm{ClO}_{4}\right)_{2}$ placed downstream from the cuvette to minimize the confounding effect of water vapor on infrared gas analyzer $\mathrm{CO}_{2}$ measurements. Measurements were made between 08:00 and 11:00 under clear or partly cloudy skies during the week prior to each harvest in July and August of 1994. During measurements, $\mathrm{CO}_{2}$ partial pressure and air temperature in the cuvette averaged $34.2 \pm 1.1 \mathrm{~Pa}$ (mean $\pm \mathrm{SD}$ ) and $27 \pm 0.7^{\circ} \mathrm{C}$, respectively.

Photosynthetic photon flux density (PPFD) incident on the leaf surface was controlled with a red light-emitting diode (LED) array (model 1000A, Quantum Devices, Barneveld, Wis.), and photosynthesis was measured at seven PPFDs ranging from 10 to $1800 \mu \mathrm{mol} \cdot \mathrm{m}^{-2} \cdot \mathrm{s}^{-1}$ (in a descending sequence: 1800, 1000, 500, 200, 100, 50, and $\left.10 \mu \mathrm{mol} \cdot \mathrm{m}^{-2} \cdot \mathrm{s}^{-1}\right)$. Preliminary tests at the Baraboo site failed to reveal a significant difference, for any of the three species, between photosynthetic rates measured under red (LED) versus natural light (using neutral density filters). Photosynthetic light responses were generated with these data using the nonlinear model of Hanson et al. (1988). When model predictions were regressed against actual measures of photosynthesis for a given species and plot, the slope and intercept never differed significantly from 1 and 0 , respectively, and the $r^{2}$ always exceeded 0.9. Model output included rates of light-saturated net photosynthesis, compensation PPFD, and apparent quantum yield for individual leaves. 
Light responses were combined with data on the temporal distribution of PPFD during the photoperiod in each plot (see light monitoring methods below) to simulate diurnal patterns of area-based photosynthesis during the July-August interval in 1994. An estimate of net photosynthesis was generated for every PPFD measurement, and the average of these values was determined for each species $\times$ plot combination. We reiterate the caveat accompanying similar efforts (e.g., Beaudet et al. 2000) that, although this average reflects the constraint of PPFD on photosynthesis under otherwise favorable conditions, it does not incorporate the potentially important but presently unmeasured limits imposed by other extrinsic (e.g., air temperature and leaf-to-air vapor pressure gradient) or intrinsic factors (e.g., intracanopy shading and temporal patterns of leaf enzymatic acclimation to light variation).

In early June 1995, germinants of oak and aspen, along with 1 -year-old seedlings of maple, were again transplanted into the three fenced understory plots (integrated PPFD $\leq 2.5 \mathrm{~mol} \cdot \mathrm{m}^{-2} \cdot$ day $^{-1}$ ) at Baraboo. The aspen seed source was the same as that in 1994, while oak acorns and a sufficient supply of maple seedlings were collected from the Baraboo site. In mid-July and mid-August of that year, shoot dark respiration was measured on these seedlings to explore its potential role as a determinant of species variation in understory carbon balance. Respiration was measured during the morning on three or four individuals per species in each plot with the LCA-2 gas analyzer and a Parkinson conifer cuvette. The entire shoot (foliage and stem) was placed in the cuvette, which was covered with dark cloth and kept in the shade. During measurements, $\mathrm{CO}_{2}$ partial pressure and air temperature in the cuvette averaged $37.5 \pm 1.5 \mathrm{~Pa}$ and $27 \pm 0.9^{\circ} \mathrm{C}$, respectively. Based on regression analyses within and across species, we did not detect a significant influence $(P>0.5)$ of temperature variation on dark respiration rates. Shoots were dried to a constant mass at $70^{\circ} \mathrm{C}$ and weighed, and respiration rate was expressed on a dry mass basis.

\section{Monitoring plot light environment}

In each plot, instantaneous measures of PPFD (incident on a horizontal surface) were recorded every $15 \mathrm{~min}$ from dawn to dusk on several days between the July and August harvests in 1994. At least three galium arsenide photodiodes (Hammamatsu Photonics Corporation, Middlesex, N.J.) were positioned near each plot center (but no less than $1 \mathrm{~m}$ apart) at the average height of the seedling canopy and attached to a LI-1000 data logger (LI-COR Inc., Lincoln, Nebr.). Data from a completely clear day and one with uniform overcast (maximum PPFD $<600 \mu \mathrm{mol} \cdot \mathrm{m}^{-2} \cdot \mathrm{s}^{-1}$ ) were pooled to derive plot averages (based on about 120 measures per sensor) of integrated PPFD $\left(\mathrm{mol} \cdot \mathrm{m}^{-2} \cdot \mathrm{day}^{-1}\right)$. We chose this combination, which was also used to estimate average leaf photosynthesis, because data on percent cloud cover from a meteorological station (University of Wisconsin Agricultural Experiment Station, Madison) located within $50 \mathrm{~km}$ of both sites indicated that sky conditions during the July-August interval in 1994 were about evenly split between clear and overcast. We note that the integrated PPFD from our selected 2-day sample $\left(33.3 \mathrm{~mol} \cdot \mathrm{m}^{-2}\right.$. day $\left.{ }^{-1}\right)$ was almost identical to that $\left(33.6 \mathrm{~mol} \cdot \mathrm{m}^{-2} \cdot \mathrm{day}^{-1}\right)$ calculated from data collected at the same meteorological station throughout the JulyAugust interval.

In August 1994, two hemispherical canopy photographs were taken in each plot, converted to digital images and analyzed with SolarCalc (version 5.10; Chazdon and Field 1987), which generated independent estimates of integrated PPFD (diffuse plus direct beam, based on a midsummer solar track). These values were used to corroborate the accuracy of photodiode data in characterizing plot light environment. The two estimates of integrated PPFD were closely correlated. For example, based on data from clear days, daily integrated $\mathrm{PPFD}_{\text {photodiode }}=0.74+0.96$ (daily integrated $\left.\mathrm{PPFD}_{\text {canopy photo }}\right), r^{2}=0.94, P<0.0001, n=11$.

\section{Statistical analysis}

Relationships among RGR, its morphological and physiological determinants, and light availability were examined within and across species, light environments, and sites with linear regression using PROC GLM in SAS (SAS Institute Inc. 1999). No significant site effects or site by PPFD interactions were detected for any parameter. PROC GLM was also used in the analysis of variance (ANOVA) of tissue starch and shoot respiration data. Homogeneity of variance was tested with Levene's method (Milliken and Johnson 1989), and when heteroscedasticity was found, the data were transformed (e.g., with natural logarithm) prior to ANOVA. In analyses of tissue starch concentration and shoot respiration data, Fisher's protected least squares difference test was used to identify significant differences among species means. Unless specified otherwise, plot means for each species were the experimental units in analyses, and regressions and differences among means were declared significant if $P \leq 0.05$.

In woody and herbaceous species, RGR and organ mass ratios often vary with plant mass (e.g., Ledig et al. 1970; McConnaughay and Coleman 1999), and this can confound the analysis of plant responses to environment. Therefore, RGR and organ mass ratios were normalized (within species) to a common mass in the analysis of their responses to light environment when the following occurred: (i) RGR or organ mass ratios were found to be significantly related to seedling mass, (ii) there was sufficient overlap in the distribution of seedling mass across light environments, and (iii) there was no significant interactive effect of seedling mass and integrated PPFD on the dependent variable. Normalization was accomplished with analysis of covariance, using the LSMEANS option in PROC GLM in SAS. As is often required (Walters et al. 1993b; Kruger and Reich 1997c), seedling mass was transformed to its natural logarithm to generate a linear covariate. A lack of overlap in the distribution of seedling mass between oak and maple precluded normalization across species. In none of the three species was percent mass allocation to any organ during the July-August growth interval significantly correlated with seedling mass (data not shown).

\section{Results}

\section{Survival and growth across light environments}

During the July-August interval in 1994, integrated PPFD, calculated as an average of the integrated PPFD on one clear and one overcast day, ranged from 0.9 to $23 \mathrm{~mol} \cdot \mathrm{m}^{-2} \cdot \mathrm{day}^{-1}$ across the 11 plots, or $2.6-69 \%$ of the light available above the forest overstory during those 2 days. The coefficient of variation in integrated PPFD within plots averaged 5.9\% (range $1.8 \%$ in high light to $14.7 \%$ in the darkest plot).

In the three darkest plots (integrated PPFD $\leq 2.3$ $\left.\mathrm{mol} \cdot \mathrm{m}^{-2} \cdot \mathrm{day}^{-1}\right)$, no aspen seedlings persisted through the entirety of the 1994 growing season (Fig. 1A). When integrated PPFD equaled or exceeded $2.5 \mathrm{~mol} \cdot \mathrm{m}^{-2} \cdot \mathrm{day}^{-1}$, percent survival of aspen in 1994 was similar to or higher than that of oak and maple (mean 90, 89, and 75\%, respectively, across the remaining eight plots). Survival was not formally monitored in 1995, but in the fourth darkest plot (integrated PPFD $2.5 \mathrm{~mol} \cdot \mathrm{m}^{-2} \cdot \mathrm{day}^{-1}$ ), all of the aspen seedlings left after the fall harvest in 1994 died before the end of the 1995 growing season.

For each species, RGR during July-August 1994 was significantly and positively correlated with integrated PPFD (Fig. 1B, Table 1). Aspen growth was most responsive to light availability, as it increased more or less continuously throughout much of the PPFD range, showing no clear evi- 
dence of light saturation. In contrast, the RGR of maple and oak responded modestly to increasing integrated PPFD beyond $5 \mathrm{~mol} \cdot \mathrm{m}^{-2} \cdot \mathrm{day}^{-1}$. Compared with those in high light, RGR rankings were reversed in the two darkest plots, where surviving aspen seedlings actually lost mass through time. Growth patterns observed in July-August closely resembled those for net relative growth during the entire 1994 growing season (Fig. 1C, Table 1) as well as the 2-year study $(1994+1995$; Fig. 1D, Table 1). As a consequence of these trends, mean stem height of aspen at the end of the 1995 growing season exceeded that of oak and maple by more than 12 -fold ( 3.1 vs. 0.24 and $0.18 \mathrm{~m}$, respectively) in the plot with the highest integrated PPFD (data not shown). Height varied less $(0.35 \mathrm{~m}$ for aspen, $0.17 \mathrm{~m}$ for oak, and $0.15 \mathrm{~m}$ for maple) in the darkest plot in which aspen remained at the end of 1995 (integrated PPFD $4.4 \mathrm{~mol} \cdot \mathrm{m}^{-2} \cdot$ day $^{-1}$ ).

\section{Responses of growth determinants to light environment}

Light-saturated rates of area-based photosynthesis $\left(A_{\text {area }}\right)$ were significantly and positively related to integrated PPFD for all three species (Fig. 2, Table 1). On the other hand, light-saturated rates of mass-based photosynthesis $\left(A_{\text {mass }}\right)$ were positively correlated with PPFD only in the case of aspen; for neither oak nor maple was there a discernible trend along the light gradient (Fig. 2, Table 1). In high light, aspen had the highest photosynthetic maximum, followed by oak and then maple. The same high-light ranking occurred for estimated average photosynthesis, although it varied much less than the light-saturated rate. Both light-saturated and average photosynthesis converged as light availability decreased, and particularly for average rates, species differences were slight in the darkest environments. For example, $A_{\text {mass }}$ in the three darkest plots (integrated PPFD $\leq 2.3 \mathrm{~mol} \cdot \mathrm{m}^{-2} \cdot$ day $^{-1}$ ) averaged 22,17 , and $14 \mathrm{nmol} \cdot \mathrm{g}^{-1} \cdot \mathrm{s}^{-1}$ for aspen, maple, and oak, respectively, and differences in these rates were not significant (based on $n=3$ plot means).

Apparent quantum yield $\left(\mathrm{QY}, \mathrm{mol} \mathrm{CO}_{2} \cdot(\mathrm{mol} \mathrm{PPFD})^{-1}\right)$, calculated as the slope of the photosynthetic light response at compensation PPFD, generally decreased with increasing light availability (Fig. 3, Table 1). Overall, oak tended to have the highest QY, followed by aspen and then maple. However, aspen's QY fell well below that of maple in the three darkest plots. Compensation PPFD (CPFD) increased with light availability for all three species, but responses to increasing light diminished beyond an integrated PPFD of 5 $\mathrm{mol} \cdot \mathrm{m}^{-2} \cdot \mathrm{day}^{-1}$ (Fig. 3, Table 1). The slope of this trend did not vary $(P>0.10)$ across species (based on the model $\mathrm{CPFD}=a+b(\ln$ PPFD $)$, but oak had a significantly higher intercept than aspen and maple.

As was observed for light-saturated $A_{\text {mass }}$, aspen's leaf $\mathrm{N}$ concentration $\left(N_{\text {mass }}\right)$ was positively correlated with integrated PPFD $(P=0.01)$ during July-August 1994 , while no clear pattern was evident for either maple or oak (Fig. 4, Table 1). As a result, the three species had a similar $N_{\text {mass }}$ in the darkest plots, while aspen's $N_{\text {mass }}$ roughly doubled maple's $N_{\text {mass }}$ in high light. The corollary to this finding was a positive overall relationship $(P<0.0001)$ between lightsaturated $A_{\text {mass }}$ and $N_{\text {mass }}$ (Fig. 5). Species did not vary significantly in either the slope $(P>0.29)$ or intercept $(P>$ $0.15)$ of this trend. For each species, the growth interval average for SLA was strongly and negatively related to light
Fig. 1. Percent seedling survival at the end of the 1994 growing season (A), relative growth rate $\left(\mathrm{mg} \cdot \mathrm{g}^{-1} \cdot \mathrm{day}^{-1}\right)$ during the JulyAugust interval in 1994 (B), total relative growth $\left(\mathrm{g} \cdot \mathrm{g}^{-1}\right)$ in 1994 (C), and total relative growth $\left(\mathrm{g} \cdot \mathrm{g}^{-1}\right)$ through 1994 and 1995 (D) as a function of integrated photosynthetic photon flux density (PPFD, mol $\cdot \mathrm{m}^{-2} \cdot \mathrm{day}^{-1}$, measured during July-August 1994). Symbols show species means from each of the 11 plots, except that aspen data were missing (due to complete mortality) in the darkest plots in Figs. 1C and 1D. Regression statistics for aspen (- - ), maple (----), and oak (-) are presented in Table 1.

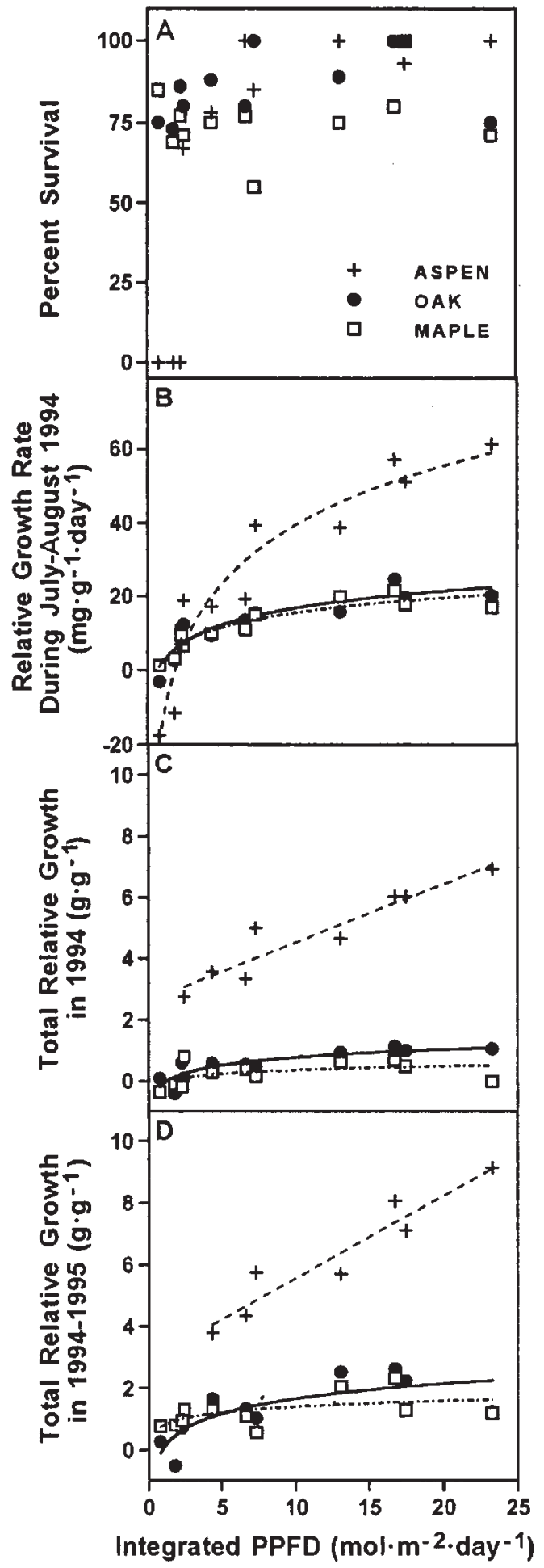


Table 1. Statistical parameters for the relationships among growth, its physiological determinants, and light availability illustrated in Figs. 1-4 and 6.

\begin{tabular}{|c|c|c|c|c|c|c|}
\hline \multirow[b]{2}{*}{ Species } & \multicolumn{6}{|c|}{ Regression parameters and coefficients } \\
\hline & $Y^{*}$ & $a$ & $b$ & $X^{\dagger}$ & $P$ & $r^{2}$ \\
\hline \multicolumn{7}{|c|}{ Relative growth rate during July-August 1994 versus integrated PPFD } \\
\hline Aspen & RGR & -14.7 & 23.4 & $\ln$ PPFD & $<0.0001$ & 0.92 \\
\hline Oak & RGR & 1.4 & 6.7 & ln PPFD & $<0.0001$ & 0.84 \\
\hline Maple & RGR & 2.0 & 5.9 & ln PPFD & $<0.0001$ & 0.89 \\
\hline \multicolumn{7}{|c|}{ Total relative growth in 1994 versus integrated PPFD } \\
\hline Aspen & $\mathrm{RG}_{1994}$ & 2.6 & 0.19 & PPFD & 0.0004 & 0.89 \\
\hline Oak & $\mathrm{RG}_{1994}$ & -0.1 & 0.38 & ln PPFD & 0.0007 & 0.74 \\
\hline Maple & $\mathrm{RG}_{1994}$ & -0.1 & 0.19 & ln PPFD & 0.09 & 0.28 \\
\hline \multicolumn{7}{|c|}{ Total relative growth in $1994+1995$ versus integrated PPFD } \\
\hline Aspen & $\mathrm{RG}_{1994+1995}$ & 2.9 & 0.27 & PPFD & 0.001 & 0.91 \\
\hline Oak & $\mathrm{RG}_{1994+1995}$ & 0.0 & 0.70 & $\ln$ PPFD & 0.008 & 0.61 \\
\hline Maple & $\mathrm{RG}_{1994+1995}$ & 0.8 & 0.27 & ln PPFD & 0.07 & 0.31 \\
\hline \multicolumn{7}{|c|}{ Light-saturated area-based photosynthesis versus integrated PPFD } \\
\hline Aspen & $A_{\text {area }}$ & 2.7 & 0.74 & PPFD & $<0.0001$ & 0.92 \\
\hline Oak & $A_{\text {area }}$ & 5.7 & 0.31 & PPFD & $<0.0001$ & 0.85 \\
\hline Maple & $A_{\text {area }}$ & 3.4 & 0.07 & PPFD & 0.03 & 0.42 \\
\hline \multicolumn{7}{|c|}{ Light-saturated mass-based photosynthesis versus integrated PPFD } \\
\hline Aspen & $A_{\text {mass }}$ & 163 & 16.7 & PPFD & 0.0003 & 0.78 \\
\hline \multicolumn{7}{|c|}{ Mean area-based photosynthesis versus integrated PPFD } \\
\hline Aspen & $A_{\text {area }}$ & 0 & 0.40 & PPFD & $<0.0001$ & 0.95 \\
\hline Oak & $A_{\text {area }}$ & 0.4 & 0.30 & PPFD & $<0.0001$ & 0.94 \\
\hline Maple & $A_{\text {area }}$ & 0.1 & 0.90 & ln PPFD & $<0.0001$ & 0.88 \\
\hline \multicolumn{7}{|c|}{ Mean mass-based photosynthesis versus integrated PPFD } \\
\hline Aspen & $A_{\text {mass }}$ & -11 & 71.2 & ln PPFD & $<0.0001$ & 0.85 \\
\hline Oak & $A_{\text {mass }}$ & -1 & 31.1 & ln PPFD & $<0.0001$ & 0.90 \\
\hline Maple & $A_{\text {mass }}$ & 9 & 20.4 & ln PPFD & $<0.0001$ & 0.86 \\
\hline \multicolumn{7}{|c|}{ Apparent quantum yield versus integrated PPFD } \\
\hline Oak & QY & 0.070 & -0.0009 & PPFD & 0.07 & 0.32 \\
\hline Maple & QY & 0.055 & -0.0009 & PPFD & 0.03 & 0.43 \\
\hline \multicolumn{7}{|c|}{ Compensation PPFD versus integrated PPFD } \\
\hline Aspen & CPFD & 14 & 5.2 & ln PPFD & 0.002 & 0.69 \\
\hline Oak & CPFD & 21 & 4.8 & $\ln$ PPFD & 0.008 & 0.56 \\
\hline Maple & CPFD & 15 & 3.2 & $\ln$ PPFD & 0.006 & 0.59 \\
\hline \multicolumn{7}{|c|}{ Leaf $\mathbf{N}$ concentration versus integrated PPFD } \\
\hline Aspen & $N_{\text {mass }}$ & 2.1 & 0.072 & PPFD & 0.01 & 0.54 \\
\hline \multicolumn{7}{|c|}{ Specific leaf area versus integrated PPFD } \\
\hline Aspen & SLA & 54.2 & -8.76 & ln PPFD & $<0.0001$ & 0.95 \\
\hline Oak & SLA & 27.2 & -3.93 & ln PPFD & $<0.0001$ & 0.85 \\
\hline Maple & SLA & 36.1 & -4.31 & $\ln$ PPFD & $<0.0001$ & 0.85 \\
\hline \multicolumn{7}{|c|}{ Leaf mass ratio versus integrated PPFD } \\
\hline Oak & LMR & 0.39 & 0.003 & PPFD & 0.02 & 0.46 \\
\hline \multicolumn{7}{|c|}{ Stem mass ratio versus integrated PPFD } \\
\hline Oak & SMR & 0.13 & -0.003 & PPFD & 0.02 & 0.47 \\
\hline \multicolumn{7}{|c|}{ Allocation to leaf mass versus integrated PPFD } \\
\hline Maple & ALM & 3.8 & 1.21 & PPFD & $<0.0001$ & 0.84 \\
\hline
\end{tabular}

availability in July-August 1994 ( $P<0.0001$; Fig. 4, Table 1). The relationship varied among species: aspen had a higher intercept $(P<0.0001)$ and steeper slope $(P \leq 0.0002)$ than the others (based on the model SLA $=a+b(\ln$ PPFD)), and maple's intercept was higher than oak's $(P<0.0001)$.
At the July 1994 harvest, evidence of light-mediated variation in mass distribution was restricted to a modest increase in oak LMR $(P=0.02)$, and a corresponding decline in SMR $(P=0.02)$, with increasing light availability (Fig. 6). Averaged across light environments, aspen had a higher LMR, 
Fig. 2. Relationship between light-saturated or simulated average photosynthesis, expressed on a leaf-area $\left(\mu \mathrm{mol} \cdot \mathrm{m}^{-2} \cdot \mathrm{s}^{-1}\right)$ and leaf-mass $\left(\mathrm{nmol} \cdot \mathrm{g}^{-1} \cdot \mathrm{s}^{-1}\right)$ basis, and integrated photosynthetic photon flux density (PPFD, mol $\cdot \mathrm{m}^{-2} \cdot \mathrm{day}^{-1}$, measured during July-August 1994 ). Symbols show species means, based on data pooled across July and August harvests, from each of the 11 plots. Regression statistics for aspen (- - ), maple (----), and oak (-) are presented in Table 1.

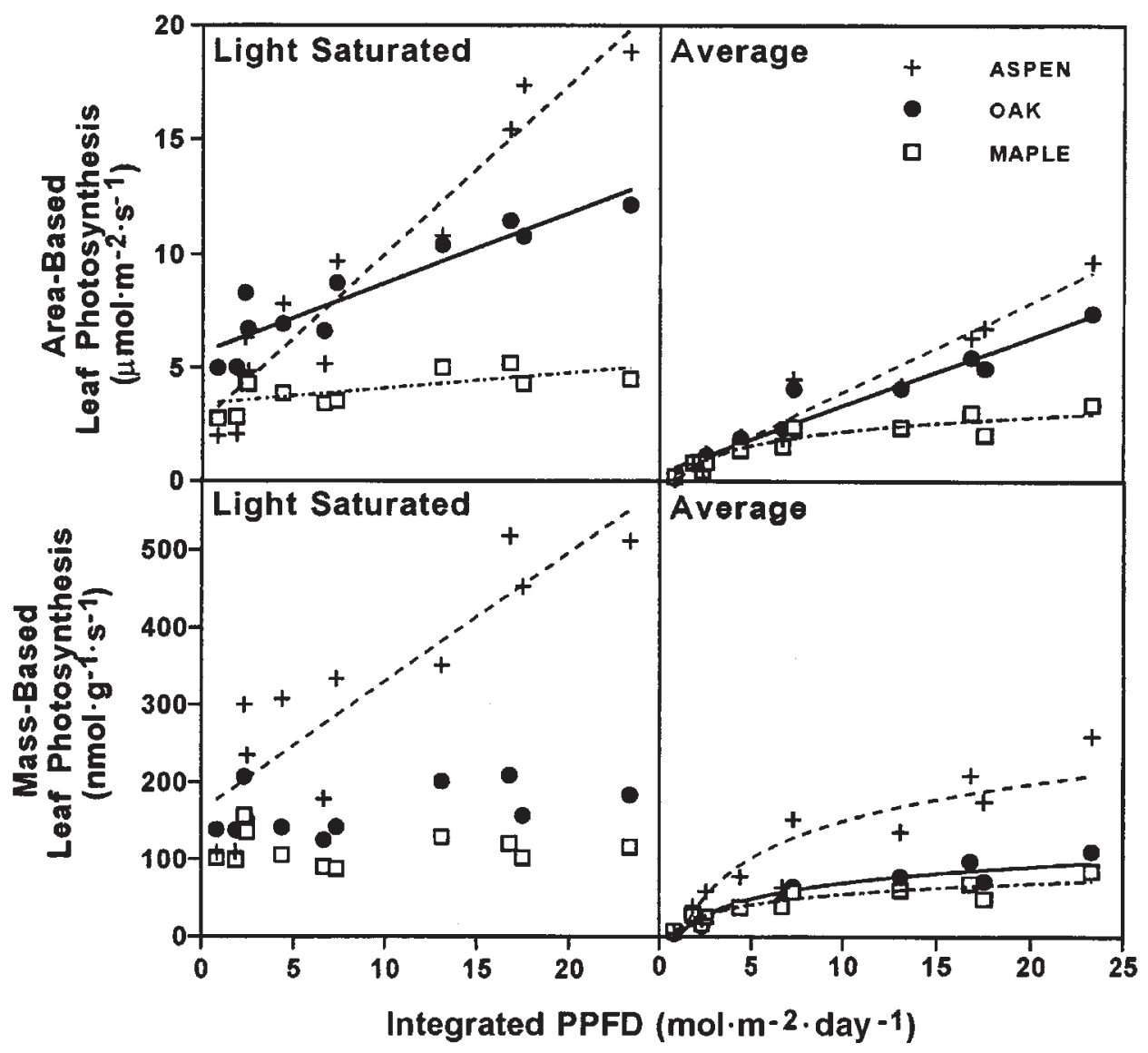

higher SMR, and lower RMR than the others $(P<0.0001$ in all cases). Additionally, oak had a higher LMR and lower SMR than maple $(P<0.0001)$. We note, however, that species comparisons should be interpreted with caution, as they are not based on a common seedling mass owing to the lack of overlap in mass distributions of oak and maple.

Detectable influences of light environment on patterns of mass allocation during the July-August interval (Fig. 6) were confined to a positive correlation between percent allocation to leaves and light availability in maple $(P<0.0001)$. Across light environments, aspen allocated significantly more mass to foliage than did oak. Aspen also ranked highest and oak lowest in percent allocation to stems, and these rankings were reversed for allocation to roots. In August 1994, the concentration of starch in leaves, stems, and roots did not vary significantly across light environments for any species $(P>0.20$, data not shown $)$, and on average it was much lower in aspen than in oak or maple $(P<0.05)$, especially for stem and root tissue (Table 2).

During July-August 1995, average rates of shoot dark respiration for the newly planted seedlings in low-light plots (integrated PPFD $\leq 2.3 \mathrm{~mol} \cdot \mathrm{m}^{-2} \cdot \mathrm{day}^{-1}$ ) at Baraboo varied by threefold among species (Table 2). The respiration rate of oak was slightly but nonsignificantly higher than that of maple, and both were significantly lower than aspen's rate.

\section{Relationships between RGR and its determinants}

Within and across species and light environments, RGR was positively related $(P<0.0001)$ to simulated averages for area-based leaf photosynthesis (Fig. 7). However, the relationship resembled that between growth and light availability, as the RGR of aspen diverged from those of maple and oak at higher photosynthetic rates. This disparity largely disappeared when RGR was regressed against simulated averages of photosynthesis per unit leaf mass (Fig. 7). Across all data, RGR was not significantly related to SLA, LMR, or their product, leaf area ratio $(P>0.30$, data not shown). However, it was closely related $\left(r^{2}=0.93\right)$ to simulated averages for photosynthesis per gram seedling mass (Fig. 7), the product of growth interval means of average $A_{\text {area }}$, SLA, and LMR (Lambers and Poorter 1992; Walters et al. 1993b; Kruger and Reich 1997c). In neither this relationship nor that between RGR and average $A_{\text {mass }}$ did species vary significantly in the slope $(P>0.47)$ or intercept $(P>0.16)$. However, aspen data from the darkest two plots were significant outliers in each of these regression models; aspen's RGR in 
Fig. 3. Responses of apparent quantum yield $\left(\mathrm{mol} \cdot \mathrm{mol}^{-1}\right)$ and compensation PPFD $\left(\mu \mathrm{mol} \cdot \mathrm{m}^{-2} \cdot \mathrm{s}^{-1}\right)$ to integrated photosynthetic photon flux density $\left(\mathrm{PPFD}, \mathrm{mol} \cdot \mathrm{m}^{-2} \cdot\right.$ day $^{-1}$, measured during July-August 1994). Symbols show species means, based on data pooled across July and August harvests, from each of the 11 plots. With the exception of aspen quantum yield, regression statistics for aspen (- - -), maple (-.---), and oak (-) are presented in Table 1. The curve for aspen is a third-order polynomial meant for illustration only.

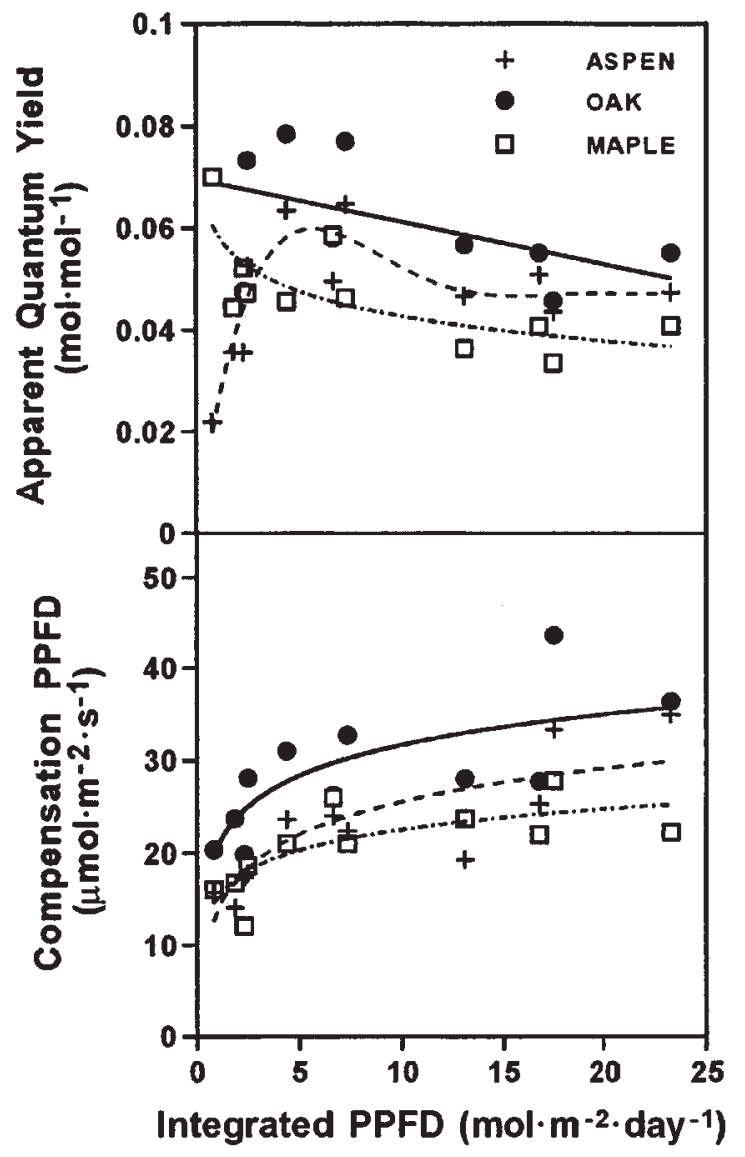

these plots was negative and much lower than others with similar rates of photosynthesis.

\section{Discussion}

Trembling aspen and sugar maple commonly co-occur with northern red oak in upland deciduous forests of the northern United States and southern Canada, and they represent opposite extremes in the broad spectrum of tree species ecologies and competitive characteristics encountered on mesic sites in these forests. Correspondingly, in this study they exhibited trade-offs in RGR, survival, and net rates of $\mathrm{CO}_{2}$ exchange at low versus moderately high light availabilities that matched expected behaviors of early- and latesuccessional species (Grime 1979; Bazzaz 1979). This included the reversal in species growth rankings in very low light, an outcome predicted by the theory of shifting competitive hierarchies (Latham 1992) but at odds with the results of several studies, wherein species' relative performances remained constant across a wide range of light environments
Fig. 4. Responses of leaf nitrogen concentration (\%) and specific leaf area $\left(\mathrm{m}^{2} \cdot \mathrm{kg}^{-1}\right)$ to integrated photosynthetic photon flux density (PPFD, mol $\cdot \mathrm{m}^{-2} \cdot \mathrm{day}^{-1}$, measured during July-August 1994). $\mathrm{N}$ concentration was analyzed on leaf samples from each species and plot pooled across individuals harvested in July and August of 1994. For specific leaf area, symbols show species means, based on data pooled across July and August harvests, from each of the 11 plots. Statistics for aspen (- - ), maple (--.-), and oak (-) regressions with a $P<0.10$ are presented in Table 1.

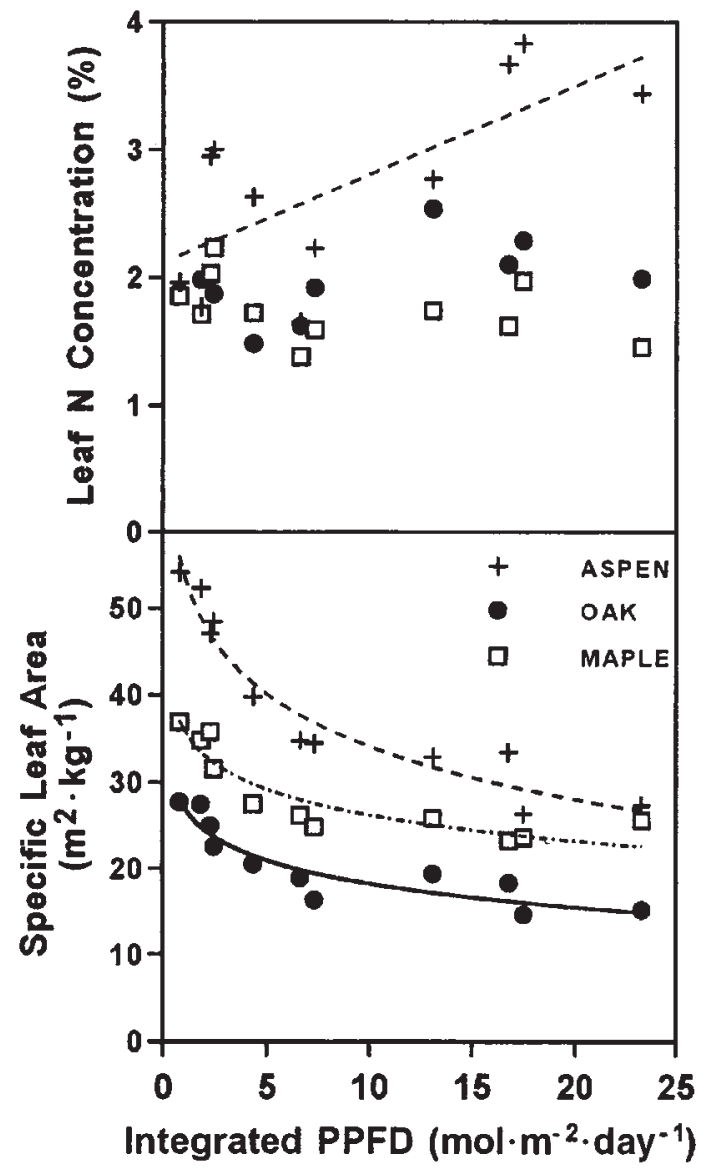

(Walters et al. 1993; King 1991; Kitajima 1994; Beaudet and Messier 1998). This reversal, which has been observed elsewhere (Pacala et al. 1994; Walters and Reich 1996, $2000 a$ ), lends further support to the tenet that shade or understory tolerance depends at least in part on the ability to maximize net carbon gain or minimize net carbon loss in dimly lit understories (Givnish 1988; Walters and Reich 1999).

On the other hand, our comparison of species' RGR and physiological variation along the light-availability gradient revealed no particular environment to which putatively midtolerant oak was uniquely suited. Instead, with few exceptions, oak's behavior was difficult to distinguish from that of shade-tolerant maple. Both species exhibited an asymptotic growth response to increasing light that, in the case of oak, was consistent with trends observed by Phares (1971) and Gottschalk (1987) but somewhat less pronounced than responses observed by others (McGee 1968; Loach 1970; Kolb et al. 1990; Pacala et al. 1994). Maple's response also re- 
sembled that observed in previous light-gradient studies (Canham 1988; Sipe and Bazzaz 1995). Although oak and maple were similar in many respects, during the second year it appeared as though a subtle difference in carbon balance had begun to emerge between the two in deep shade. In the two plots where integrated PPFD was less than $2 \mathrm{~mol} \cdot \mathrm{m}^{-2} \cdot \mathrm{day}^{-1}$, maple's cumulative 2 -year growth tended to be higher than oak's, which was negligible or negative (Fig. 1D). Hanson et al. (1987) found that a similar light threshold was needed by oak seedlings to maintain a positive carbon balance. This having been the case, it is worth noting that among the seedlings planted but not harvested in the three understory plots at Baraboo (integrated PPFD $\leq 2.5$ $\mathrm{mol} \cdot \mathrm{m}^{-2} \cdot \mathrm{day}^{-1}$ ) in $1995,88 \%$ of the oaks (as well as $82 \%$ of the maples) were still alive as of July 2000 (E. Kruger, unpublished data).

Why was the RGR of aspen more responsive to light availability than that of oak or maple? In concert with previous findings in laboratory and forest studies (Walters et al. 1993b; Kruger and Reich 1997c), variation in seedling RGR within and across species and light environments was, for the most part, linearly related to simulated averages of photosynthesis per unit seedling mass. In our view, this provided sufficient empirical justification for a straightforward assessment of the roles of measured and estimated growth determinants (i.e., growth interval means for average $A_{\text {area }}$ SLA, and LMR) in governing RGR. In the case of aspen, for example, the enhancement of average $A_{\text {area }}$ with increasing light availability more than compensated for a substantial light-induced decrease in SLA and resulted in a more or less linear growth response throughout the range of light availability. As with oak, aspen's average $A_{\text {area }}$ was positively related to light availability not only because of an increase in usable energy but also an improved ability to use that energy (e.g., a higher light-saturated $A_{\text {area }}$ ). But unlike oak, the steep rise in aspen's light-saturated $A_{\text {area }}$ with increasing integrated PPFD was associated less with leaf thickening (stacking of photosynthetic tissue) than with a pronounced increase in light-saturated $A_{\text {mass }}$.

A positive relation between light-saturated $A_{\text {mass }}$ and light availability is not often observed (cf. Jurik 1986; Ellsworth and Reich 1992; Wayne and Bazzaz 1993; Walters et al. $1993 b)$. This uncommon response, which to our knowledge has been exhibited by only a handful of mostly early successional tree species (Callaway 1992; Kitajima 1994; Burton and Bazzaz 1995; Huante and Rincon 1998), was positively associated with leaf $N_{\text {mass }}$ in our study (Field and Mooney 1986). As in the case of $A_{\text {mass }}$, the positive correlation between aspen leaf $N_{\text {mass }}$ and light availability is inconsistent with many reports of the opposite tendency (e.g., Wayne and Bazzaz 1993; Niinemets 1997; Lusk and Reich 2000). However, it is conceivable that, in our understory environments, either soil N availability (Vitousek et al. 1989; Kim et al. 1996; Kruger and Reich 1997b) or light energy (Truax et al. 1994) could have limited the acquisition of $\mathrm{N}$ and (or) its subsequent reduction or assimilation in foliage of aspen (Min et al. 1998). As for the consequences of $\mathrm{N}$ limitation, there is evidence (Latham 1992; Coomes and Grubb 2000; Walters and Reich 2000b) that it can negatively influence the growth and survival of intolerant tree species
Fig. 5. Relationship between light-saturated rates of mass-based leaf photosynthesis $\left(\mathrm{nmol} \cdot \mathrm{g}^{-1} \cdot \mathrm{s}^{-1}\right)$ and leaf $\mathrm{N}$ concentration $(\%)$. For photosynthesis, symbols show species means of July and August data from each of the 11 plots. The $\mathrm{N}$ concentration was analyzed on leaf samples from each species and plot pooled across individuals harvested in July and August of 1994. The regression, based on data from all species, was $A_{\text {mass }}=-172+$ $171\left(N_{\text {mass }}\right), r^{2}=0.82, P<0.0001$.

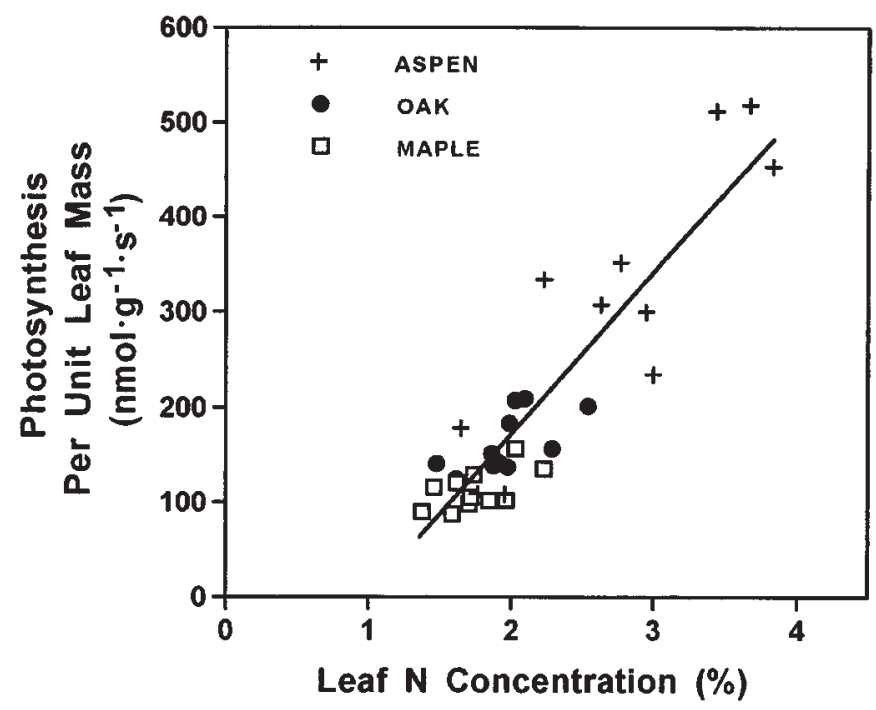

(including aspen) even at light availabilities as low as those in our understories.

For maple and oak, the relative insensitivity of lightsaturated $A_{\text {mass }}$ to integrated PPFD led to a situation where light-mediated increases in average $A_{\text {area }}$ were largely or entirely offset by decreases in SLA. Similar consequences of this trade-off between metabolism and morphology were demonstrated for a shade-tolerant herb that exhibited little variation in light-saturated $A_{\text {mass }}$ across light environments (Sims and Pearcy 1994; Sims et al. 1994). Coincidently, a carbon balance model for that herb indicated that the light response of RGR saturated at an integrated PPFD between 5 and $10 \mathrm{~mol} \cdot \mathrm{m}^{-2} \cdot \mathrm{day}^{-1}$, which was similar to that observed for oak and maple in our study.

Among the most consistent plant responses to increasing light availability is a decline in SLA (e.g., Jurik 1986), and all three species in this study displayed considerable sensitivity in this regard. Additionally, as has been frequently observed (e.g., Loach 1970; Bazzaz and Carlson 1982; Latham 1992; Walters et al. 1993a; Osunkoya et al. 1994; Huante and Rincon 1998), foliage of the intolerant, early successional species (aspen) exhibited the greatest plasticity in SLA across the light gradient, while the late-successional species (maple) was the least responsive among the three. In contrast, when the potentially confounding influence of seedling mass was taken into account, the distribution and allocation of mass to leaves, stems, and roots varied little with light availability. The notable exception was a positive response of maple foliage allocation to light availability. These findings contradict numerous investigations (e.g., Kuppers et al. 1988; Callaway 1992; Osunkoya et al. 1994) and established acclimation paradigms (reviewed by Givnish 1988; Wilson 1988) in which LMR (often considered a mea- 
Fig. 6. Variation in leaf, stem, and root mass ratios $\left(\mathrm{g} \cdot \mathrm{g}^{-1}\right)$ in July 1994 or percent mass allocation to each organ during the July-August interval, along the gradient of integrated photosynthetic photon flux density (PPFD, mol $\cdot \mathrm{m}^{-2} \cdot \mathrm{day}^{-1}$, measured during July-August 1994 ). Symbols show species means from each of the 11 plots, except for mass allocation of aspen, which was not calculated when RGR was negative (in the darkest two plots). Statistics for aspen (- - ), maple (--.-), and oak (-) regressions with a $P<0.10$ are presented in Table 1 .

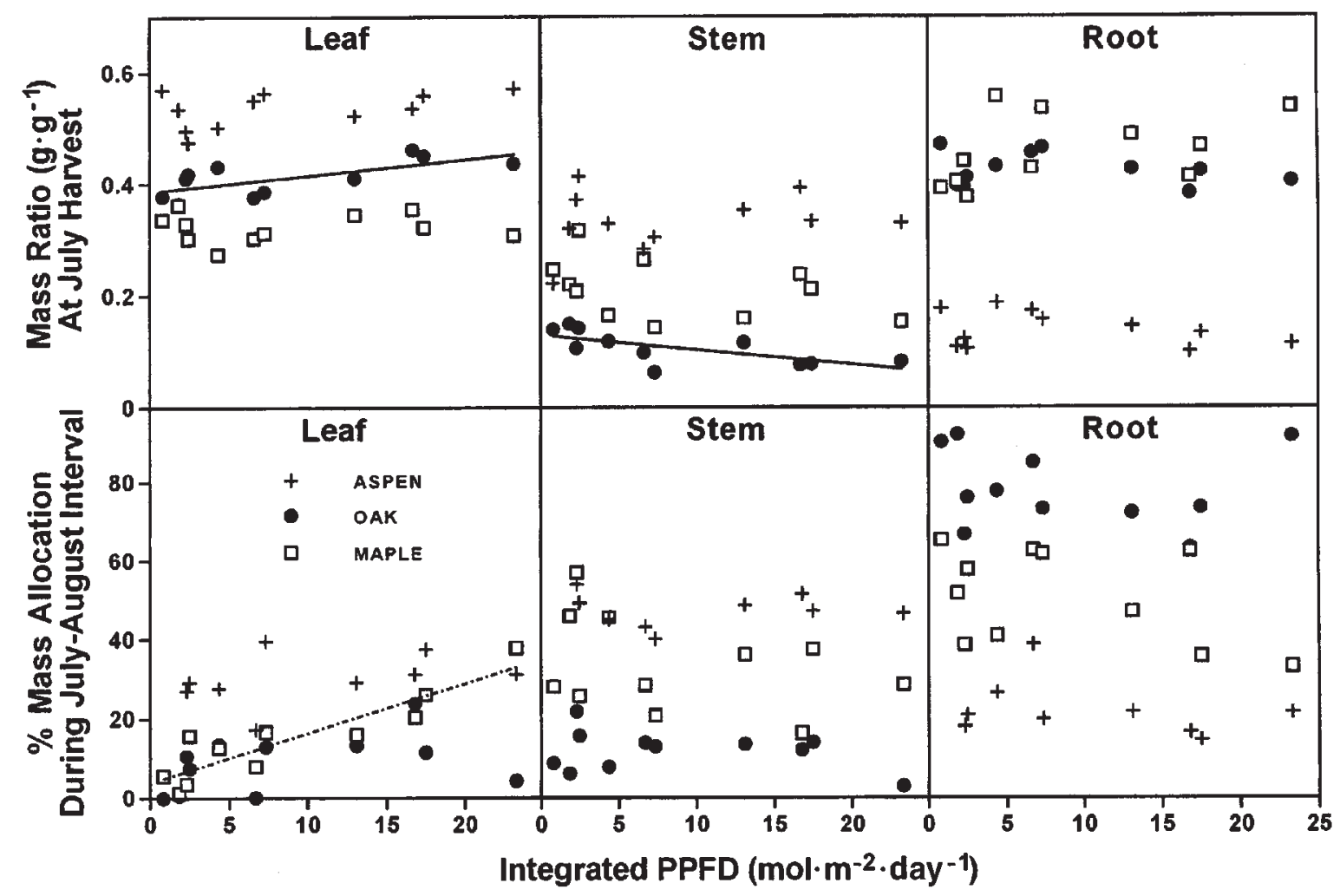

Table 2. Tissue starch concentrations of seedlings harvested from all plots in August 1994, and mean rates of shoot dark respiration measured (during the day) on newly planted seedlings in three low-light plots at Baraboo in July and August 1995.

\begin{tabular}{llll}
\hline Parameter & Aspen & Oak & Maple \\
\hline Leaf starch (\% dry mass) & $0.4(0.1) b$ & $2.2(0.8) a b$ & $3.2(0.8) a$ \\
Root and stem starch $(\%$ dry mass) & $2.7(0.5) b$ & $15.3(1.5) a$ & $11.7(0.6) a$ \\
Shoot dark respiration $\left(\mathrm{nmol} \cdot \mathrm{g}^{-1} \cdot \mathrm{s}^{-1}\right)$ at $27^{\circ} \mathrm{C}$ & $15.9(0.9) a$ & $6.2(0.7) b$ & $5.1(0.8) b$ \\
Estimated shoot dark respiration $\left(\mathrm{nmol} \cdot \mathrm{g}^{-1} \cdot \mathrm{s}^{-1}\right)$ at $15^{\circ} \mathrm{C}$ & 5.3 & 2.1 & 1.7 \\
\hline
\end{tabular}

Note: Values are means, with SE given in parentheses, based on $n=11$ plot averages in the case of starch, and $n=$ 3 plot averages in the case of shoot respiration. For a given parameter, means with different letters are significantly different at $P \leq 0.05$, based on Fisher's protected least squares difference test. Also provided is an estimate of shoot dark respiration at $15^{\circ} \mathrm{C}$, a typical nighttime temperature during midsummer in southern Wisconsin, based on a $Q_{10}$ for respiration temperature sensitivity of 2.48 , which is the average calculated from data collected by Bolstad et al. (1999) on shade-acclimated foliage of several temperate deciduous broadleaf species.

sure of allocation) generally increases in the shade, thereby enhancing a plant's ability to capture light. Alternatively, data from the present study provide further support for the suggestion that, at least among woody perennials, apparent sensitivities of organ mass ratios to light availability may often be artifacts of light-driven differences in plant size rather than modifications in mass allocation (Ledig et al. 1970; Loach 1970; Kolb et al. 1990; Walters et al. 1993; Reich et al. 1998).

Although photosynthesis per unit leaf or seedling mass explained much of the overall RGR variation in this study, there were discrepancies in these relationships in low light. Specifically, aspen's negative RGR in the darkest plots was coupled to rates of photosynthesis that corresponded with non-negative growth rates in the other species. Our estimate of average photosynthesis per unit leaf or seedling mass does not incorporate the temporal dynamics of photosynthetic acclimation to fluctuating light, which can have important implications for carbon gain, especially in the understory (Stegemann et al. 1999). Furthermore, it does not account for all components of plant carbon balance, such as tissue construction costs, root exudates, and dark respiration (Givnish 1988; Lambers and Poorter 1992). The importance of variation in many of these factors remains uncertain (Poorter 1994; Wullschleger et al. 1997), but dark respiration is clearly a pivotal determinant of net carbon balance in 
Fig. 7. Relationships between relative growth rate $\left(\mathrm{mg} \cdot \mathrm{g}^{-1} \cdot \mathrm{day}^{-1}\right)$ and simulated averages for photosynthesis per unit leaf area $\left(\mu \mathrm{mol} \cdot \mathrm{m}^{-2} \cdot \mathrm{s}^{-1}\right)$, photosynthesis per unit leaf mass $\left(\mathrm{nmol} \cdot \mathrm{g}^{-1} \cdot \mathrm{s}^{-1}\right)$, or photosynthesis per unit seedling mass (nmol $\left.\cdot(\mathrm{g} \operatorname{seedling})^{-1} \cdot \mathrm{s}^{-1}\right)$ during the JulyAugust growth interval in 1994. Symbols show species means from each of the 11 plots. No single model adequately fit the relation between RGR and photosynthesis per unit leaf area. The regression for RGR versus photosynthesis per unit leaf mass, based on all data (excluding two aspen data with negative RGRs), was RGR $=3.4+0.21\left(A_{\text {mass }}\right), r^{2}=0.89, P<0.0001$. The regression for RGR versus photosynthesis per unit seedling mass, based on all data (excluding two aspen data with negative RGRs), was RGR $=5.1+$ $0.47\left(A_{\text {seedling }}\right), r^{2}=0.93, P<0.0001$.

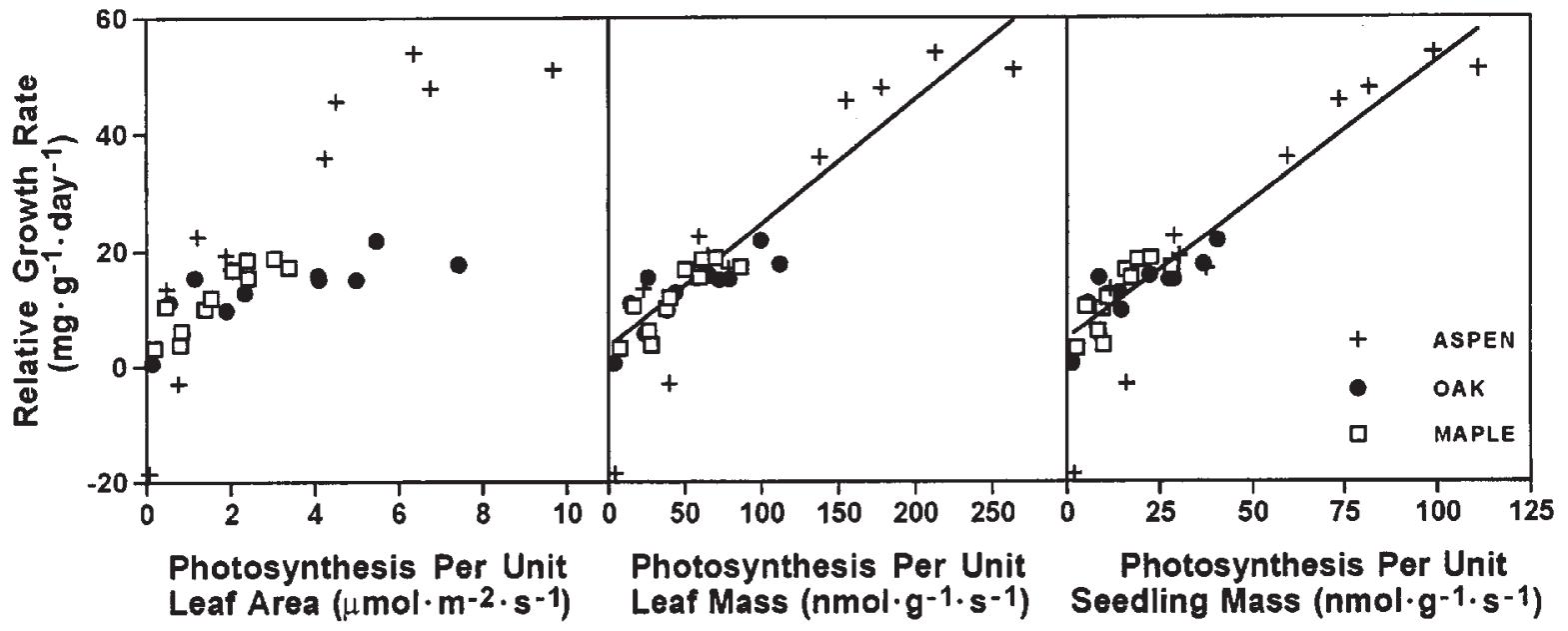

environments that constrain variation in realized photosynthesis (Loach 1967; Sims et al. 1994; Lehto and Grace 1994). Such appeared to be the case in this study, where there was a compelling link between aspen's negative RGR and comparatively high shoot dark respiration in low light.

Loach $(1967,1970)$ also found that, in $3 \%$ of full light, aspen seedlings lost mass and respired at a higher rate than did shade-tolerant tree species. Collectively, these and other recently published data on $\mathrm{CO}_{2}$ exchange of tree seedlings in low light (reviewed by Walters and Reich 1999) provide considerable support for a long-held assertion (Grime 1965) that shade tolerance is inversely related to tissue respiration rate and that variation in the latter underlies a general but poorly understood trade-off between photosynthetic capacity in moderate- to high-light environs and respiratory metabolism in low light (Reich et al. 1998; Lusk and Reich 2000; Walters and Reich 2000a). Additionally, aspen's relatively high respiration rate in this study might have reflected its preferential allocation of recently acquired photoassimilate to meristematic activity in lieu of carbohydrate storage. Aspen exhibited indeterminate shoot growth and, correspondingly, possessed low concentrations of starch reserves, in all light environments. The rate of respiration accompanying tissue construction can be severalfold higher than that generated through carbohydrate translocation and storage (Poorter 1994), which could explain at least part of the difference in respiration between aspen and the other species.

Aspen's allocation strategy, which facilitated rapid growth in moderate to high light, seemed especially risky in the understory, where a plant could face lethal carbohydrate shortages during conditions that further constrain an already marginal rate of whole-seedling photosynthesis. A lack of carbon reserves can impair basal metabolism and (or) leave seedlings vulnerable to attack and consumption by an array of other organisms. Conversely, the shoot growth of oak and maple was restricted to a single flush in low light, and starch levels were comparatively high in the stem and roots of both species, regardless of light availability. Poor survival of rapidly growing, shade-intolerant species in tropical understories has been associated not with an unfavorable carbon balance per se but rather an increased susceptibility to herbivores, pathogens, and (or) mechanical damage (Augspurger 1984; Coley 1988; Kitajima 1994). Grime (1965) and others (Pacala et al. 1994; Lehto and Grace 1994; Kobe 1997; DeLucia et al. 1998; Canham et al. 1999) have suggested and (or) provided evidence that the maintenance of a sizable carbohydrate reserve, rather than the maximization of carbon uptake, may be critical for resistance to biotic and abiotic stresses and persistence in the understory. It is increasingly apparent that there are trade-offs between morphological and physiological traits that promote rapid growth and those that enhance survival in stressful environments (Givnish 1988; Kitajima 1994; Walters and Reich 1996, 1999).

The results of this field study further elucidate, from a whole-plant perspective, the physiology underlying lightdependent variation in growth and survival among tree species of contrasting successional status in temperate deciduous forests. In particular, they help to clarify the regeneration ecology of northern red oak on mesic sites. Based on our observations, oak's growth rate, morphology, resource allocation, and leaf physiology generally align with those of a shade-tolerant species. From our standpoint, the importance of this inference is that it does not point to any unique physiological predicament faced by oak seedlings in mesic forest environments. Thus, we are compelled to refocus attention on other hypotheses explaining the present inability of oak regeneration to consistently recruit into new or existing canopies in the eastern deciduous forest. Among these is the growing realization that oak regeneration failures may often be consequences of relatively recent and widespread increases in browsing pressure by deer and other mammals (Johnson 1993; Lorimer 1993; Gordon et al. 1995; 
Buckley et al. 1998; Stange and Shea 1998). Another widely held belief, supported by historical evidence (Abrams 1992), is that the chances of successful oak regeneration increase considerably in forest ecosystems subjected to repeated cycles of fire or other disturbances that create and maintain a favorable plant community in which young oaks can thrive and develop at a reasonable pace. However, the utility of fire as a regeneration tool remains unclear, especially on mesic sites (Kruger and Reich 1997a, 1997b, 1997c). We are currently testing these hypotheses and their potential interrelationships in southern Wisconsin.

With respect to current silvicultural strategies aimed at promoting oak regeneration, our findings provide only equivocal support for any specific manipulation of understory light environment, as we found no position along the light-availability continuum where oak possessed a relative growth advantage. If anything, these results justify the recommendation that enhancements of light availability to the oak regeneration layer should be modest on mesic sites (Johnson 1984; Pubanz and Lorimer 1992). Based on the growth responses we observed, increases beyond $20 \%$ of full light afforded little benefit to oak seedlings and instead preferentially stimulated the vigor of a less tolerant, rapidly growing species. We point out, however, that our inferences are necessarily restricted to seedling-stage individuals, and there is evidence that growth responses of larger oaks (e.g., saplings) to light availability may differ from those reported here (Pacala et al. 1994; Finzi and Canham 2000; J. Goodburn and C. Lorimer, unpublished data).

\section{Acknowledgments}

We are very grateful to Rachel and Don Jordan and Richard and Melanie Mielke for letting us conduct this project in their woodlands and for their continuing support of oak ecology research. Financial support was provided by the University of Wisconsin-Madison, and the USDA competitive grants program (grant No. CRGO-USDA 90-37290-5686). Tissue starch analyses were conducted in the laboratory of Dr. Richard Lindroth (Department of Entomology, University of Wisconsin, Madison). Aspen seeds were provided by Dr. Egon Humenberger, North Central Experiment Station, University of Minnesota. We also thank Anne Benson, Paul Kloppenburg, and Stephanie Seiger for their invaluable contributions to the project.

\section{References}

Abrams, M.D. 1992. Fire and the development of oak forests. Bioscience, 42: 346-353.

Ashby, W.C. 1976. Basswood seedlings outgrow red and bur oak in full light or heavy shade. USDA For. Serv. Tree Plant. Notes 27. pp. 24-26.

Augspurger, C.K. 1984. Seedling survival of tropical tree species: interactions of dispersal distance, light-gaps, and pathogens. Ecology, 65: 1705-1712.

Bazzaz, F.A. 1979. The physiological ecology of plant succession. Annu. Rev. Ecol. Syst. 10: 351-372.

Bazzaz, F.A., and Carlson, R.W. 1982. Photosynthetic acclimation to variability in the light environment of early and late successional plants. Oecologia, 54: 313-316.
Bazzaz, F.A., and Wayne, P.M. 1994. Coping with environmental heterogeneity: the physiological ecology of tree seedling regeneration across a gap-understory continuum. In Exploitation of environmental heterogeneity by plants. Edited by M.M. Caldwell and R.W. Pearcy. Academic Press, San Diego, Calif. pp. 349-390.

Beaudet, M., and Messier, C. 1998. Growth and morphological responses of yellow birch, sugar maple, and beech seedlings growing under a natural light gradient. Can. J. For. Res. 28: 1007-1015.

Beaudet, M., Messier, C., Hilbert, D.W., Lo, E., Wang, Z.M., and Lechowicz, M.J. 2000. Leaf- and plant-level carbon gain in yellow birch, sugar maple, and beech seedlings from contrasting forest light environments. Can. J. For. Res. 30: 390-404.

Bolstad, P.V., Mitchell, K., and Vose, J.M. 1999. Foliar temperature-respiration response functions for broad-leaved tree species in the southern Appalachians. Tree Physiol. 19: 871-878.

Buckley, D.S., Sharik, T.L., and Isebrands, J.G. 1998. Regeneration of northern red oak: positive and negative effects of competitor removal. Ecology, 79: 65-78.

Burns, R.M., and Honkala, B.H. (Technical coordinators). 1990. Silvics of North America. Vol. 2. Hardwoods. U.S. Dep. Agric. Agric. Handb. 654.

Burton, P.J., and Bazzaz, F.A. 1995. Ecophysiology of tree seedlings invading different patches of old-field vegetation. J. Ecol. 83: 99-112.

Callaway, R.M. 1992. Morphological and physiological responses of three California oak species to shade. Int. J. Plant Sci. 153: 434-441.

Canham, C.D. 1988. Growth and canopy architecture of shadetolerant trees: response to canopy gaps. Ecology, 69: 786-795.

Canham, C.D., and Marks, P.L. 1985. The response of woody plants to disturbance: patterns of establishment and growth. In The ecology of natural disturbance and patch dynamics. Edited by S.T.A. Pickett and P.S. White. Academic Press, Orlando, Fla. pp. 197-216.

Canham, C.D., Denslow, J.S., Platt, W.J., Runkle, J.R., Spies, T.A., and White, P.S. 1990. Light regimes beneath closed canopies and tree-fall gaps in temperate and tropical forests. Can. J. For. Res. 20: 620-631.

Canham, C.D., Kobe, R.K., Latty, E.F., and Chazdon, R.L. 1999. Interspecific and intraspecific variation in tree seedling survival: effects of allocation to roots versus carbohydrate reserves. Oecologia, 121: 1-11.

Chazdon, R.L., and Field, C.B. 1987. Photographic estimation of photosynthetically active radiation: evaluation of a computerized technique. Oecologia, 73: 525-532.

Coley, P.D. 1988. Effects of plant growth rate and leaf lifetime on the amount and type of anti-herbivore defense. Oecologia, 74: 531-536.

Coomes, D.A., and Grubb, P.J. 2000. Impacts of root competition in forests and woodlands: a theoretical framework and review of experiments. Ecol. Monogr. 70: 171-207.

Crow, T.R. 1988. Reproductive mode and mechanisms for selfreplacement of northern red oak (Quercus rubra) - a review. For. Sci. 34: 19-40.

Curtis, J.T. 1959. The vegetation of Wisconsin. University of Wisconsin Press, Madison.

DeLucia, E.H., Sipe, T.W., Herrick, J., and Maherali, H. 1998. Sapling biomass allocation and growth in the understory of a deciduous hardwood forest. Am. J. Bot. 85: 955-963.

Dickson, R.E. 1991. Assimilate distribution and storage. In Physiology of trees. Edited by A.S. Raghavendra. John Wiley \& Sons, New York. pp. 51-85. 
Dillenburg, L.R., Teramura, A.H., Forseth, I.N., and Whigham, D.F. 1995. Photosynthetic and biomass allocation responses of Liquidambar styraciflua (Hamamelidaceae) to vine competition. Am. J. Bot. 82: 454-461.

Ellsworth, D.S., and Reich, P.B. 1992. Leaf mass per area, nitrogen content, and photosynthetic carbon gain in Acer saccharum seedlings in contrasting forest light environments. Funct. Ecol. 6: 423-435.

Evans, G.C. 1972. The quantitative analysis of plant growth. Blackwell Scientific Publications, Oxford, U.K.

Farmer, R.E., Jr. 1975. Growth and assimilation rate of juvenile northern red oak: effects of light and temperature. For. Sci. 21: 373-381.

Farmer, R.E. 1980. Comparative analysis of 1st year growth in six deciduous tree species. Can. J. For. Res. 10: 35-41.

Field, C., and Mooney, H.A. 1986. The photosynthesis-nitrogen relationship in wild plants. In On the economy of plant form and function. Edited by T. Givnish. Cambridge University Press, Cambridge, U.K. pp. 25-55.

Finzi, A.C., and Canham, C.D. 2000. Sapling growth in response to light and nitrogen availability in a southern New England forest. For. Ecol. Manage. 131: 153-165.

Geis, J.W., Tortorelli, R.L., and Boggess, W.R. 1971. Carbon dioxide assimilation of hardwood seedlings in relation to community dynamics in central Illinois. Oecologia, 7: 276-289.

Givnish, T.J. 1988. Adaptation to sun and shade: a whole-plant perspective. Aust. J. Plant Physiol. 15: 63-92.

Gordon, A.M., Simpson, J.A., and Williams, P.A. 1995. Six-year response of red oak seedlings planted under a shelterwood in central Ontario. Can. J. For. Res. 25: 603-613.

Gottschalk, K.W. 1987. Effects of shading on growth and development of northern red oak, black oak, black cherry, and red maple seedlings, 2. Biomass partitioning and prediction. In Proceedings of the Central Hardwood Forest Conference, 24-26 Feb. 1987, Knoxville, Tenn. Edited by R.L. Hay, F.W. Woods, and H. DeSelm. University of Tennessee, Knoxville. pp. 269-276.

Grime, J.P. 1965. Shade tolerance in flowering plants. Nature (London), 208: 161-163.

Grime, J.P. 1979. Plant strategies and vegetation processes. John Wiley \& Sons, Chichester, U.K.

Hanson, P.J., Isebrands, J.G., and Dickson, R.E. 1987. Carbon budgets of Quercus rubra L. seedlings at selected stages of growth: influence of light. In Proceedings of the Central Hardwood Forest Conference, 24-26 Feb. 1987, Knoxville, Tenn. Edited by R.L. Hay, F.W. Woods, and H. DeSelm. University of Tennessee, Knoxville. pp. 269-276.

Hanson, P.J., Isebrands, J.G., Dickson, R.E., and Dixon, R.K. 1988. Ontogenetic patterns of $\mathrm{CO}_{2}$ exchange of Quercus rubra L. leaves during three flushes of shoot growth. I. Median flush leaves. For. Sci. 34: 55-68.

Huante, P., and Rincon, E. 1998. Responses to light changes in tropical deciduous woody seedlings with contrasting growth rates. Oecologia, 113: 53-66.

Johnson, P.S. 1984. Responses of planted red oak to three overstory treatments. Can. J. For. Res. 14: 536-542.

Johnson, P.S. 1993. Perspectives on the ecology and silviculture of oak-dominated forests in the central and eastern states. USDA For. Serv. Gen. Tech. Rep. NC-153.

Jurik, T.W. 1986. Temporal and spatial patterns of specific leaf weight in successional northern hardwood tree species. Am. J. Bot. 73: 1083-1092.

Keddy, P.A. 1989. Competition. Chapman \& Hall, London.

Kim, C., Sharik, T.L., Jurgensen, M.F., Dickson, R.E., and Buckley, D.S. 1996. Effects of nitrogen availability on northern red oak seedling growth in oak and pine stands in northern Lower Michigan. Can. J. For. Res. 26: 1103-1111.

King, D.A. 1991. Correlations between biomass allocation, relative growth rate, and light environment in tropical forest saplings. Funct. Ecol. 5: 485-492.

Kitajima, K. 1994. Relative importance of photosynthetic traits and allocation patterns as correlates of seedling shade tolerance of 13 tropical trees. Oecologia, 98: 419-428.

Kobe, R.K. 1997. Carbohydrate allocation to storage as a basis of interspecific variation in sapling survivorship and growth. Oikos, 80: $226-233$.

Kolb, T.E., and Steiner, K.C. 1990. Growth and biomass partitioning response of northern red oak genotypes to shading and grass root competition. For. Sci. 36: 293-303.

Kolb, T.E., Steiner, K.C., McCormick, L.H., and Bowersox, T.W. 1990. Growth response of northern red oak and yellow poplar seedlings to light, soil moisture, and nutrients in relation to ecological strategy. For. Ecol. Manage. 38: 65-78.

Kruger, E.L., and Reich, P.B. 1997a. Responses of hardwood regeneration to fire in mesic forest openings. I. Post-fire community dynamics. Can. J. For. Res. 27: 1822-1831.

Kruger, E.L., and Reich, P.B. 1997b. Responses of hardwood regeneration to fire in mesic forest openings. II. Leaf gas exchange, nitrogen concentration, and water status. Can. J. For. Res. 27: 1832-1840.

Kruger, E.L., and Reich, P.B. 1997c. Responses of hardwood regeneration to fire in mesic forest openings. III. Whole-plant growth, biomass distribution, and carbohydrate and nutrient relations. Can. J. For. Res. 27: 1841-1850.

Kuppers, M., Koch, G., and Mooney, H.A. 1988. Compensating effects to growth of changes in dry matter allocation in response to variation in photosynthetic characteristics induced by photoperiod, light, and nitrogen. Aust. J. Plant Physiol. 15: 287-298.

Lambers, H., and Poorter, H. 1992. Inherent variation in growth rate between higher plants: a search for physiological causes and ecological consequences. Adv. Ecol. Res. 23. pp. 188-261.

Latham, R.E. 1992. Co-occurring tree species change rank in seedling performance with resources varied experimentally. Ecology, 73: 2129-2144.

Ledig, F.T., Bormann, F.H., and Wenger, K.F. 1970. The distribution of dry matter growth between shoot and roots in loblolly pine. Bot. Gaz. 131: 349-359.

Lehto, T., and Grace, J. 1994. Carbon balance of tropical tree seedlings: a comparison of two species. New Phytol. 127: 455-463.

Lindroth, R.L., Kinney, K.K., and Platz, C.L. 1993. Responses of deciduous trees to elevated atmospheric $\mathrm{CO}_{2}$ : productivity, phytochemistry, and insect performance. Ecology, 74: 763-777.

Loach, K. 1967. Shade tolerance in tree seedlings, 1. Leaf photosynthesis and respiration in plants raised under artificial shade. New Phytol. 66: 607-621.

Loach, K. 1970. Shade tolerance in tree seedlings, 2. Growth analysis of plants raised under artificial shade. New Phytol. 69: 273-286.

Lorimer, C.G. 1989. The oak regeneration problem: new evidence on causes and possible solutions. College of Agricultural and Life Sciences, University of Wisconsin, Madison. For. Resour. Anal. 8.

Lorimer, C.G. 1993. Causes of the oak regeneration problem. In Oak regeneration: serious problems, practical recommendations. USDA For. Serv. Gen. Tech. Rep. SE-84. pp. 14-39.

Lorimer, C.G., Chapman, J.W., and Lambert, W.D. 1994. Tall understory vegetation as a factor in the poor development of oak seedlings beneath mature stands. J. Ecol. 82: 227-237. 
Lusk, C.H., and Reich, P.B. 2000. Relationships of leaf dark respiration with light environment and tissue nitrogen content in juveniles of 11 cold-temperate tree species. Oecologia, 123: 318-329.

McConnaughay, K.D.M., and Coleman, J.S. 1999. Biomass allocation in plants: ontogeny or optimality? A test along three resource gradients. Ecology, 80: 2581-2593.

McGee, C.E. 1968. Northern red oak seedling growth varies by light intensity and seed source. USDA For. Serv. Res. Note SE-90.

Messier, C., Doucet, R., Ruel, J.C., Claveau, Y., Kelly, C., and Lechowicz, M.J. 1999. Functional ecology of advance regeneration in relation to light in boreal forests. Can. J. For. Res. 29: 812-823.

Milliken, G.A., and Johnson, D.E. 1989. Analysis of messy data. Chapman \& Hall, New York.

Min, X., Siddiqi, M.Y., Guy, R.D., Glass, A.D.M., and Kronzucker, H.J. 1998. Induction of nitrate uptake and nitrate reductase activity in trembling aspen and lodgepole pine. Plant Cell Environ. 21: 1039-1046.

Musselman, R.C., and Gatherum, G.E. 1969. Effects of light and moisture on red oak seedlings. Iowa State J. Sci. 43: 273-284.

Niinemets, U. 1997. Role of foliar nitrogen in light harvesting and shade tolerance of four temperate deciduous woody species. Funct. Ecol. 11: 518-531.

Osunkoya, O.O., Ash, J.E., Hopkins, M.S., and Graham, A.W. 1994. Influence of seed size and seedling ecological attributes on shade-tolerance of rain-forest tree species in northern Queensland. J. Ecol. 82: 149-163.

Pacala, S.W., Canham, C.D., Silander, J.A., and Kobe, R.K. 1994. Sapling growth as a function of resources in a north temperate forest. Can. J. For. Res. 24: 2172-2183.

Pallardy, S.G., Nigh, T.A., and Garrett, H.E. 1988. Changes in forest composition in central Missouri: 1968-1982. Am. Midl. Nat. 120: $380-390$.

Pearcy, R.W. 1987. Photosynthetic gas exchange responses of Australian tropical forest trees in canopy, gap, and understory micro-environments. Funct. Ecol. 1: 169-178.

Phares, R.E. 1971. Growth of red oak (Quercus ruba L.) seedings in relation to light and nutrients. Ecology, 52: 669-672.

Poorter, H. 1994. Construction costs and payback time of biomasss: a whole-plant perspective. In A whole-plant perspective on carbon-nitrogen interactions. Edited by J. Roy and E. Garnier. SPB Academic Publishing, The Hague, the Netherlands. pp. 111-127.

Pubanz, D.M., and Lorimer, C.G. 1992. Oak regeneration experiments in southwestern Wisconsin: two year results. School of Natural Resources, College of Agricultural and Life Sciences, University of Wisconsin, Madison. Publ. R3552.

Reich, P.B., Abrams, M.D., Ellsworth, D.S., Kruger, E.L., and Tabone, T.J. 1990. Fire affects ecophysiology and community dynamics of central Wisconsin oak forest regeneration. Ecology, 71: 2179-2190.

Reich, P.B., Walters, M.B., Tjoelker, M.G., Vanderklein, D., and Buschena, C. 1998. Photosynthesis and respiration rates depend on leaf and root morphology and nitrogen concentration in nine boreal forest species differing in relative growth rate. Funct. Ecol. 12: 395-405.

SAS Institute Inc. 1999. SAS user's guide: statistics. SAS Institute Inc., Cary, N.C.

Schulte, E.E., Peters, J.B., and Hodgson, P.R. 1987. Wisconsin procedures for soil testing, plant analysis and feed and forage analysis. Department of Soil Science, University of WisconsinExtension, Madison. Soil Fertil. Ser. 6.

Shirley, H.L. 1943. Is tolerance the capacity to endure shade? J. For. 41: 339-345.
Sims, D.A., and Pearcy, R.W. 1994. Scaling sun and shade photosynthetic acclimation of Alocasia macrorrhiza to wholeplant performance, 1. Carbon balance and allocation at different daily photon flux densities. Plant Cell Environ. 17: 881-887.

Sims, D.A., Gebauer, R.L.E., and Pearcy, R.W. 1994. Scaling sun and shade photosynthetic acclimation of Alocasia macrorrhiza to whole-plant performance, 2. Simulation of carbon balance and growth at different photon flux densities. Plant Cell Environ. 17: 889-900.

Sipe, T.W., and Bazzaz, F.A. 1995. Gap partitioning among maples (Acer) in central New England: survival and growth. Ecology, 76: $1587-1602$.

Spencer, J.S., and Kingsley, N.P. 1991. The oak resource in the upper midwest: an overview. In The Oak Resource in the Upper Midwest: Implications for Management. Conference Proceedings, 3-6 June 1991, Winona, Minn. St. Mary’s College, Winona, Minn. pp. 11-17.

Stange, E.E., and Shea, K.L. 1998. Effects of deer browsing, fabric mats, and tree shelters on Quercus rubra seedlings. Restor. Ecol. 6: $29-34$.

Stegemann, J., Timm, H.C., and Kuppers, M. 1999. Simulation of photosynthetic plasticity in response to highly fluctuating light: an empirical model integrating dynamic photosynthetic induction and capacity. Trees, 14: 145-160.

Stephens, G.R., and Ward, J.S. 1992. Sixty years of natural change in unmanaged mixed hardwood forests. Conn. Agric. Exp. Stn. Bull. 902.

Toumey, J.W., and Kienholz, R. 1931. Trenched plots under forest canopies. Yale Univ. Sch. For. Bull. 30.

Truax, B., Lambert, F., Gagnon, D., and Chevrier, N. 1994. Nitrate reductase and glutamine synthetase activities in relation to growth and nitrogen assimilation in red oak and red ash seedlings: effects of $\mathrm{N}$-forms, $\mathrm{N}$ concentration and light intensity. Trees, 9: 12-18.

U.S. Department of Agriculture (USDA). 1962. Soil survey of Iowa County, Wisconsin. USDA Soil Conservation Service, Washington, D.C.

U.S. Department of Agriculture (USDA). 1980. Soil survey of Sauk County, Wisconsin. USDA Soil Conservation Service, Washington, D.C.

U.S. Department of Commerce. 1994. Climatological data, Wisconsin bulletin. U.S. Department of Commerce, National Oceanic and Atmospheric Administration, Asheville, N.C.

Vitousek, P.M., Van Cleve, K., and Matson, P.A. 1989. Nitrogen availability and nitrification during succession: primary, secondary and old-field series. Plant Soil, 115: 229-239.

Walters, M.B., and Reich, P.B. 1996. Are shade tolerance, survival, and growth linked? Low light and nitrogen effects on hardwood seedlings. Ecology, 77: 841-853.

Walters, M.B., and Reich, P.B. 1999. Low-light carbon balance and shade tolerance in the seedlings of woody plants: do winter deciduous and broad-leaved evergreen species differ? New Phytol. 143: $143-154$.

Walters, M.B., and Reich, P.B. 2000a. Trade-offs in low-light $\mathrm{CO}_{2}$ exchange: a component of variation in shade tolerance among cold temperate seedlings. Funct. Ecol. 14: 155-165.

Walters, M.B., and Reich, P.B. 2000b. Seed size, nitrogen supply, and growth rate affect tree seedling survival in deep shade. Ecology, 81: 1887-1901.

Walters, M.B., Kruger, E.L., and Reich, P.B. 1993a. Growth, biomass distribution and $\mathrm{CO}_{2}$ exchange of northern hardwood seedlings in high and low light: relationships with successional status and shade tolerance. Oecologia, 94: 7-16. 
Walters, M.B., Kruger, E.L., and Reich, P.B. 1993b. Relative growth rate in relation to physiological and morphological traits for northern hardwood tree seedlings: species, light environment and ontogenetic considerations. Oecologia, 96: 219-231.

Wayne, P.M., and Bazzaz, F.A. 1993. Birch seedling responses to daily time courses of light in experimental forest gaps and shadehouses. Ecology, 74: 1500-1515.
Wilson, J.B. 1988. A review of evidence on the control of shoot:root ratio, in relation to models. Ann. Bot. (London), 61: 433-449.

Wullschleger, S.D., Norby, R.J., Love, J.C., and Runck, C. 1997. Energetic costs of tissue construction in yellow-poplar and white oak trees exposed to long-term $\mathrm{CO}_{2}$ enrichment. Ann. Bot. (London), 80: 289-297. 